Check for updates

Cite this: Mater. Adv., 2020, 1,728

Received 11th March 2020

Accepted 22nd May 2020

DOI: $10.1039 / \mathrm{d} 0 \mathrm{ma} 00096 \mathrm{e}$

rsc.li/materials-advances

\title{
Biogenic synthesis of a silver nanoparticle- SnZrMoP nanocomposite and its application for the disinfection and detoxification of water
}

\author{
Rupinder Kaur, ${ }^{a}$ Sandeep Kaushal (D) ${ }^{b}$ and Prit Pal Singh ${ }^{b}$
}

\begin{abstract}
A silver nanoparticle (AgNP)-tin zirconium(Iv) molybdophosphate (SnZrMoP) nano-composite was synthesized by a superficial and green synthetic approach using mulberry leaf extract, with the plant extract playing the role of a reducing agent as well as a capping agent. The nanocomposite was characterized by Fourier-transform infrared spectroscopy (FTIR), scanning electron microscopy (SEM), transmission electron microscopy (TEM), energy dispersive $X$-ray spectroscopy (EDX), X-ray diffraction (XRD), and thermogravimetric analysis (TGA). The chemical stability of the nanocomposite and the effect of calcination on the ion-exchange capacity of the nanocomposite were also investigated. The nanocomposite was observed to be highly selective for $\mathrm{Ba}^{2+}$ and $\mathrm{Sr}^{2+}$ ions on the basis of distribution coefficient studies. The applications of the nanocomposite as an antimicrobial agent and for the quantitative and selective separation of toxic $\mathrm{Ba}^{2+}$ and $\mathrm{Sr}^{2+}$ ions from industrial effluents were explored.
\end{abstract}

\section{Introduction}

The natural habitats of living organisms have been depleted with the illimitable flourishing of industrialization and unrestrained pollution. The expulsion of industrial waste into the environment has added many major pollutants to ecosystems, such as pesticides, antibiotics, and heavy metals. The presence of even traces of heavy metals in natural water bodies can cause major health hazards to humans and animals. ${ }^{1}$ The metals of particular concern in industrial effluents are cadmium, chromium, lead, mercury, silver, arsenic, aluminium, copper, cobalt, manganese, and barium. Being a divalent-alkaline earth metal, barium forms salts with carbonates, nitrates, chlorides, and sulphides and thus has been widely employed in different fields, such as brickmaking, ceramic glaze, cement, glass, paint, and plastic

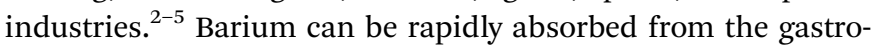
intestinal tract and deposited in the muscles, lungs, and bones. ${ }^{6}$ A low dose of barium can act as a muscle stimulant, but higher doses of barium can have an adverse impact on the nervous system and can lead to cardiac irregularities, weakness, anxiety, shortness of breath, and paralysis. Industrial emissions are the main source of barium in the atmosphere.

Nanomaterials of different sizes, shapes, and compositions have found comprehensive applications. Metallic nanoparticles

\footnotetext{
${ }^{a}$ Guru Nanak Dev Polytechnic College, Ludhiana, Punjab, India

${ }^{b}$ Department of Chemistry, Sri Guru Granth Sahib World University, Fatehgarh Sahib, Punjab, India. E-mail: dhillonps2003@gmail.com, kaushalsandeep33@gmail.com; Fax: +91-1763-234236; Tel: +91-84270-00415, +91-7009795652
}

among these materials are of great interest because of their inimitable optical, electrical, and electrochemical properties. ${ }^{7,8}$ Among the various metal nanoparticles, silver nanoparticles (AgNPs) are of immense interest because of their versatile applications as antimicrobial agents, biosensor materials, composite fibers, cryogenic superconductor materials, cosmetic products, and electronic components.

The synthesis of AgNPs can be carried out by a number of techniques, like laser ablation, gamma irradiation, electron irradiation, chemical reduction, photochemical methods, microwave processing, and biological synthetic methods. ${ }^{9}$ However, the majority of routes for the synthesis of nanoparticles encompass the use of hazardous chemicals or high energy requirements. To overcome these demerits, biogenic nanoparticles synthesized from plant extracts without making use of any poisonous chemicals would be considered attractive for nanotechnology. ${ }^{10}$ The phytochemicals present in plants are water soluble and can cause the immediate reduction of metal ions. ${ }^{11}$

A number of medicinal plants, such as Acorus calamus, Alternanthera dentate, Ocimum sanctum, Azadirachta indica, Brassica rapa, Coccinia indica, Vitex negundo, Solanum xanthcarpum, Croton bonplandianum, Andrographis paniculata, and Cleome viscosa, have been reported in literature for the synthesis of biogenic $\mathrm{Ag}$ nanoparticles. ${ }^{12-20}$ In this paper, we have reported a low-cost facile approach for the synthesis of silver nanoparticles from the mulberry leaf extract. Nanosized inorganic particles and cluster-based nanocomposites represent materials with the most appropriate properties for various applications. $^{21,22}$ Inorganic cation exchangers have already 
been employed as a support to disperse and stabilize numerous nanoparticles. ${ }^{23,24}$

In the present work, AgNPs were synthesized from mulberry leaf extract in an environment friendly process. The AgNPSnZrMoP composite was synthesized by the incorporation of biogenic silver nanoparticles (GAgNPs) in an SnZrMoP ion exchanger. The nanocomposite was found to be highly selective for $\mathrm{Ba}^{2+}$ and $\mathrm{Sr}^{2+}$ ions. The as-synthesized nanocomposite was employed for the efficient removal of $\mathrm{Ba}^{2+}$ ions from industrial effluents, and as an antimicrobial agent to inhibit the growth of E. coli and Bacillus. To the best of our knowledge, there is no report in literature regarding the use of a hybrid nanocomposite of biogenic silver nanoparticles and SnZrMoP ion exchanger for the disinfection and detoxification of water.

\section{Experimental}

\section{Reagents and instruments}

Zirconium oxychloride, stannic chloride, sodium molybdate, sodium dihydrogen phosphate, ethylene diamine tetra acetic acid, silver nitrate, and all other chemicals and reagents were purchased from Loba Chemie, India and used as received. A single electrode $\mathrm{pH}$ meter (Toshniwal, India) was used for the $\mathrm{pH}$ studies. Fourier transform infrared (FTIR) spectra were recorded on a PerkinElmer RX1 FTIR spectrometer. X-ray diffraction (XRD) patterns were obtained using a PAN analytical system DY 3190 $\mathrm{X}$-ray diffractometer. Scanning electron microscopy (SEM) images were obtained from an S-4800 field emission SEM system (JEOL scanning electron microscope) equipped to perform elemental chemical analysis by energy dispersive X-ray spectroscopy (EDX). Transmission electron microscopy (TEM) studies were performed using the MIC JEM 2100. Thermal analysis was performed by heating the nanocomposite material up to $900{ }^{\circ} \mathrm{C}$ at a constant increment of $10{ }^{\circ} \mathrm{C}$ per minute in a nitrogen atmosphere, using Hitachi SGA7400 thermogravimetric analyzer. UV-vis spectra were recorded in a quartz cuvette using a Shimadzu-UV 2600 spectrophotometer.

\section{Preparation of the reagents}

Solutions of zirconium oxychloride and stannic chloride (0.1 M) were prepared in $1 \mathrm{M} \mathrm{HCl}$ solution. Sodium dihydrogen phosphate $(0.1 \mathrm{M})$, sodium molybdate $(0.1 \mathrm{M})$, silver nitrate
$(0.1,0.2,0.3$, and $0.4 \% \mathrm{w} / \mathrm{v})$ and EDTA $(0.01 \mathrm{M})$ solutions were prepared in double-distilled water (DDW).

\section{Synthesis of an inorganic gel of tin zirconium(Iv) molybdophosphate (SnZrMoP)}

Tin zirconium(Iv) molybdophosphate samples were prepared at room temperature $\left(25 \pm 2{ }^{\circ} \mathrm{C}\right)$ by mixing $0.1 \mathrm{M}$ solutions of each of sodium molybdate, sodium dihydrogen phosphate, stannic chloride, and zirconium oxychloride in different volume ratios. Ethylene diamine tetra acetic acid (0.01 M EDTA) was used as a capping agent. ${ }^{25}$ Each solution of the salts was added into the EDTA solution kept under a constant stirring with a magnetic stirrer. The $\mathrm{pH}$ of the mixture was adjusted to $0-1$ by adding aqueous ammonia or hydrochloric acid with constant stirring, and a white colored gel was obtained as the final product.

\section{Synthesis of green silver nanoparticles (GAgNPs)}

The leaf extract was prepared from air dried and finely crushed mulberry leaves. The extract was then filtered using Whatman no. 1 filter paper, to remove the particulate matter. Different concentrations of $\mathrm{AgNO}_{3}$ solution $(0.1,0.2,0.3,0.4$, and $0.5 \% \mathrm{w} / \mathrm{v})$ were prepared for optimization. For the reduction of $\mathrm{Ag}^{+}$ions to $\mathrm{Ag}$, mulberry leaf extract was added to silver nitrate $\left(\mathrm{AgNO}_{3}\right)$ solution with continuous stirring for $1 \mathrm{~h}$ at room temperature. Due to the surface plasmon resonance phenomenon, the color of the solution changed from colorless to pale yellow, and finally reddish brown, indicating the complete reduction of $\mathrm{AgNO}_{3}$.

\section{Synthesis of the GAgNPs-SnZr(Iv) MoP nanocomposite}

Four different samples of GAgNPs-SnZrMoP nanocomposite were prepared by varying the molar concentration of silver nitrate solution while keeping the volume ratio of different components of the inorganic counterpart constant (Table 1). The resultant slurry was kept for $24 \mathrm{~h}$ and then washed repeatedly with DDW. The material was filtered off and washed thoroughly with DDW to remove the excess acid. The filtered gel was dried at a temperature of $40{ }^{\circ} \mathrm{C}$ in a hot air oven. The dried product was immersed in DDW to obtain small granules. The resultant product was saturated with hydrogen ions by keeping the granules in $0.1 \mathrm{M} \mathrm{HCl}$ solution for $24 \mathrm{~h}$ with periodic stirring, and by changing the solution to get better results. After $24 \mathrm{~h}$, the granules were filtered out and washed a number of times to remove the excess acid, and then dried at $50 \pm 2{ }^{\circ} \mathrm{C}$ till a constant weight was obtained.

Table 1 Optimization of conditions for the synthesis of the GAgNPs-SnZrMoP nanocomposite

\begin{tabular}{|c|c|c|c|c|c|c|c|c|c|c|c|}
\hline \multirow[b]{3}{*}{$\begin{array}{l}\text { Sample } \\
\text { Code }\end{array}$} & \multicolumn{8}{|c|}{ Synthesis conditions } & \multirow{2}{*}{\multicolumn{3}{|c|}{ Properties }} \\
\hline & \multicolumn{8}{|c|}{ Mixing volume ratio } & & & \\
\hline & $\begin{array}{l}\mathrm{ZC}(0.1 \mathrm{M}) \\
(\mathrm{mL})\end{array}$ & $\begin{array}{l}\mathrm{SC}(0.1 \mathrm{M}) \\
(\mathrm{mL})\end{array}$ & $\begin{array}{l}\mathrm{SM}(0.1 \mathrm{M}) \\
(\mathrm{mL})\end{array}$ & $\begin{array}{l}\text { EDTA } 0.01 \mathrm{M} \\
(\mathrm{mL})\end{array}$ & $\begin{array}{l}\operatorname{SDP}(0.1 \mathrm{M}) \\
(\mathrm{mL})\end{array}$ & $\begin{array}{l}\text { Wt of mulberry } \\
\text { leaves }(\mathrm{g})\end{array}$ & $\begin{array}{l}\text { \%age }(w / v) \text { of } \\
\operatorname{AgNO}_{3}(100 \mathrm{~mL})\end{array}$ & $\mathrm{pH}$ & $\begin{array}{l}\text { Color of } \\
\text { granules }\end{array}$ & $\begin{array}{l}\text { Yield } \\
\text { (g) }\end{array}$ & 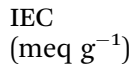 \\
\hline S-1 & 100 & 100 & 100 & 100 & 300 & - & - & 1 & White & 5.20 & 1.95 \\
\hline$S-2$ & 100 & 100 & 100 & 100 & 300 & 3.00 & 0.10 & 1 & Shiny grey & 5.55 & 2.16 \\
\hline$S-3$ & 100 & 100 & 100 & 100 & 300 & 3.00 & 0.20 & 1 & Shiny grey & 5.87 & 2.25 \\
\hline S-4 & 100 & 100 & 100 & 100 & 300 & 3.00 & 0.30 & 1 & Shiny grey & 6.12 & 2.48 \\
\hline$S-5$ & 100 & 100 & 100 & 100 & 300 & 3.00 & 0.40 & 1 & Shiny grey & 6.44 & 2.36 \\
\hline
\end{tabular}

ZC - zirconium oxychloride; SC - stannic chloride; SDP - sodium dihydrogen phosphate; SM - sodium molybdate; $\mathrm{M} \mathrm{-} \mathrm{mol} \mathrm{L}^{-1}$. 


\section{Ion-exchange capacity (IEC)}

The standard column method was used to determine the ionexchange capacity of the nanocomposite. The nanocomposite material $(0.5 \mathrm{~g})$ in $\mathrm{H}^{+}$form was placed in a glass column containing glass wool support at the bottom. The hydrogen ions eluted with $0.5 \mathrm{M} \mathrm{NaNO}$ solution were estimated by titration against a standard sodium hydroxide $(0.1 \mathrm{M})$ solution. The hydrogen ions released were then estimated by the formula:

$$
\mathrm{IEC}=\frac{N \times V}{W} \text { meq }^{-1}
$$

where $N$ and $V$ are the normality and volume in $\mathrm{mL}$ of $\mathrm{NaOH}$, respectively, and $W$ is the weight in grams of the nanocomposite. ${ }^{26}$

\section{Effect of calcination on the ion-exchange capacity}

The nanocomposite cation exchange material in $\mathrm{H}^{+}$form was heated at various temperatures for $1 \mathrm{~h}$ in the muffle furnace from $100{ }^{\circ} \mathrm{C}$ to $900{ }^{\circ} \mathrm{C}$, in increments of $10{ }^{\circ} \mathrm{C}$. The $\mathrm{Na}^{+}$ionexchange capacity was determined by a batch process, after cooling the material to room temperature. ${ }^{26}$

\section{pH-Titrations studies and functionality of the exchanger}

The Topp and Pepper method ${ }^{27}$ was used for the pH-titration studies of the GAgNPs-SnZrMoP nanocomposite. An equimolar mixture of alkali and alkaline earth metal chlorides and their corresponding hydroxide solutions in different volume ratios (total volume being $50 \mathrm{~mL}$ ) was added to each of the several $250 \mathrm{~mL}$ conical flasks containing $0.5 \mathrm{~g}$ of the nanocomposite in $\mathrm{H}^{+}$form. The $\mathrm{pH}$ of the solution was recorded every $24 \mathrm{~h}$ till the attainment of equilibrium.

\section{Chemical stability}

The nanocomposite cation exchanger $(0.2 \mathrm{~g})$ in $\mathrm{H}^{+}$form was treated separately with $50 \mathrm{~mL}$ of different concentrations of strong acid $(\mathrm{HCl})$, strong base $(\mathrm{NaOH})$, and organic solvents, like a $10 \%$ solution of each of acetone and ethyl alcohol for $24 \mathrm{~h}$, with occasional shaking. After removal of the excess reagent, the nanocomposite was dried in a hot air oven at $40 \pm 1{ }^{\circ} \mathrm{C}$ and its ion exchange capacity was determined by the batch method.

\section{Distribution studies}

The distribution coefficients $\left(K_{\mathrm{d}}\right)$ for various metal ions were determined in different solvent systems. The nanocomposite cation exchange material in $\mathrm{H}^{+}$form $(0.2 \mathrm{~g})$ was placed separately in contact with $20 \mathrm{~mL}$ solutions of each of the different metal ions for $24 \mathrm{~h}$, with occasional shaking to attain equilibrium. A standard solution of EDTA $(0.01 \mathrm{M})$ was used for estimation of the amount of metal ions in solution, before and after equilibrium. The distribution coefficient $\left(K_{\mathrm{d}}\right)$ represents the ratio of the amount of metal ions in the exchanger phase and the solution phase, and is given by:

$$
K_{\mathrm{d}}=\frac{I-F}{F} \times \frac{V}{M} \mathrm{~mL} \mathrm{~g}^{-1}
$$

where $I$ is the initial concentration of metal ions in the solution phase, $F$ is the final concentration of metal ions in the solution phase, $V$ is the volume of solution $(\mathrm{mL})$, and $M$ is the amount of ion exchanger taken $(\mathrm{g})$.

\section{Binary separations}

Quantitative separation of metal ions in binary synthetic mixtures. The cation exchanger $(1 \mathrm{~g})$ in $\mathrm{H}^{+}$form was taken in a glass column having glass wool support at the bottom. A mixture of two metal ions ( $0.01 \mathrm{M}$ each) was passed through the column (flow rate: $0.25 \mathrm{~mL} \mathrm{~min}^{-1}$ ) till the solution level was just above the surface of the exchanger. The unexchanged metal ions were removed by rinsing the column with DDW. The adsorbed metal ions on the exchanger were eluted individually using appropriate eluting reagents. The fractions $(10 \mathrm{~mL})$ of the eluent were collected and the metal ions were estimated by titration against a standard solution of EDTA $(0.01 \mathrm{M})$.

Selective separation of $\mathrm{Ba}(\mathrm{II})$ ions from a synthetic mixture. The selective separation of three different amounts of $\mathrm{Ba}^{2+}$ and $\mathrm{Sr}^{2+}$ ions (separately) from the synthetic mixtures containing a fixed amount of $\mathrm{Mg}^{2+}, \mathrm{Ca}^{2+}, \mathrm{Co}^{2+}, \mathrm{Fe}^{3+}$, and $\mathrm{Ni}^{2+}$ was achieved on the column of the GAgNPs-SnZrMoP nanocomposite.

Quantitative separation of $\mathrm{Ba}(\mathrm{II})$ ions from wastewater samples. Water soluble barium salts are used in various industrial processes and laboratories. In the chemistry lab, barium chloride solution is used as a sulfate ion indicator in the presence of hydrochloric acid, while barium carbonate is chiefly used in brick-making and ceramic industries, and barium nitrate is used to manufacture high-quality glass with a low co-efficient of thermal expansion. Environmental remediation by the GAgNPs-SnZrMoP nanocomposite was checked on wastewater samples collected from the paint industry, brick-making industry, glass industry, and chemistry laboratory. The effluent samples were filtered to remove any suspended particles and neutralized. The color-producing substances were removed by adsorption on charcoal. The waste sample $(100 \mathrm{~mL})$ was passed over the column of GAgNPs-SnZrMoP and the effluent collected was recycled three times at a flow rate of $0.5 \mathrm{~mL} \mathrm{~min}^{-1}$. The metal ions were eluted with $0.5 \mathrm{M} \mathrm{HNO}_{3}$ and were determined titrimetrically with $0.01 \mathrm{M}$ EDTA solution.

\section{Antimicrobial studies}

The antibacterial potential of GAgNPs, SnZrMoP, and the GAgNPs-SnZrMoP nanocomposite was investigated separately. At first, the cultures for E. coli and Bacillus were grown uninventivily, in an incubator preserved at $37{ }^{\circ} \mathrm{C}$ with a shaking velocity of $200 \mathrm{rpm}$. The medium-term developed culture was shifted to flasks containing $20 \mathrm{~mL}$ Luria Broth. For both E. coli and Bacillus, a control experiment was set up without the addition of any chemical. Then, $500 \mu \mathrm{L}$ of dimethyl sulfoxide (DMSO) was added in both $E$. coli and Bacillus cultures in another control experiment. In the test experiment, $50 \mathrm{mg}$ of GAgNPs, SnZrMoP, and GAgNPs-SnZrMoP was added in different flasks, followed by $1 \mathrm{~h}$ of growth in a shaker. Thereafter, a $1 \mathrm{~mL}$ culture was withdrawn from every flask after a time span of $2 \mathrm{~h}$. The optical density (OD 600 (nm)) was documented separately for individual samples and a graph was plotted of the OD $600(\mathrm{~nm})$ versus time (h) to measure the rate of growth inhibition. 


\section{Results and discussion}

A novel nanocomposite cation exchange material, GAgNPs-tinzirconium(Iv) molybdophosphate, was synthesized by embedding biogenic silver nanoparticles (GAgNPs) into a novel four-component inorganic cation exchanger tin-zirconium(Iv) molybdophosphate. In the present investigation, green silver nanoparticles were synthesized from mulberry leaf extract without using any toxic chemicals, to reduce the environmental impact caused by various conventional techniques. The synthesis conditions were optimized by varying the $\%$ age $(\mathrm{w} / \mathrm{v})$ concentration of silver nitrate solution and by keeping the volume ratios of the inorganic counterparts constant (Table 1). The ion-exchange capacity increased with the increase in doping of silver nanoparticles up to a certain extent. The sample C-4 was selected for further studies due to its highest ion-exchange capacity. The higher ion-exchange capacity of the GAgNPs-SnZrMoP nanocomposite might be due to the interaction between the GAgNPs and SnZrMoP. The synthesis was carried out in the presence of EDTA, which acted as a capping agent and a polymer, and may also be responsible for the enhanced ion-exchange capacity.

\section{Characterization of the nanocomposite}

The GAgNPs-SnZrMoP nanocomposite was characterized by UV-vis spectrophotometery (UV-vis), Fourier transform infrared (FTIR) spectroscopy, X-ray diffraction (XRD), scanning electron microscopy (SEM), transmission electron microscopy (TEM), energy dispersive X-ray (EDX), and themogravimetric analysis (TGA-DTA) studies.

UV-vis spectroscopy is the simplest and most important technique to confirm the formation of nanoparticles. The absorbance spectrum of the sample in the range of 400-800 nm, using a Shimadzu-UV 2600 spectrometer confirmed the reduction of silver ions to silver nanoparticles (Fig. 1). The absorption maximum of the bioreduced GAgNPs at different time intervals was observed as a sharp band at $460 \mathrm{~nm}$ in the UV-vis spectra.

The FTIR spectrum of SnZrMoP (Fig. 2a) showed a broad band around $3431.77 \mathrm{~cm}^{-1}$, which could be attributed to symmetric

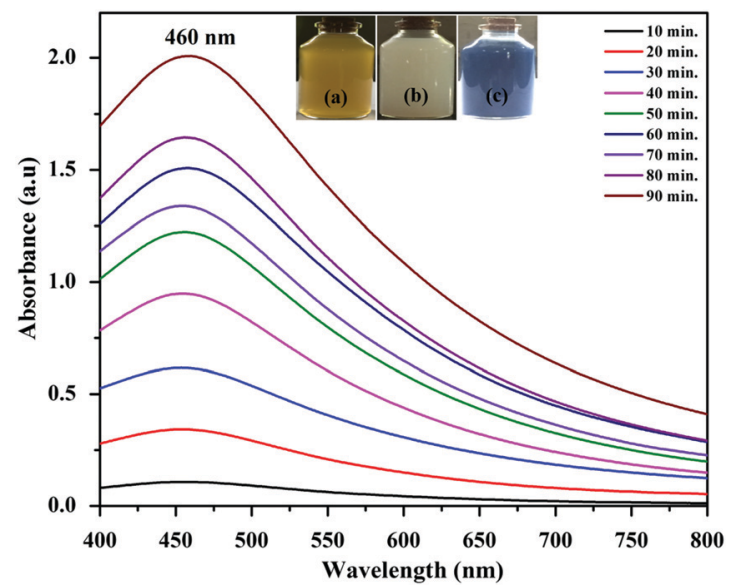

Fig. 1 UV-vis spectra of GAgNPs at different reaction times. (Inset: Images depicting the color of the synthesized (a) GAgNPs (b) SnZrMoP (c) GAgNPsSnZrMoP.)

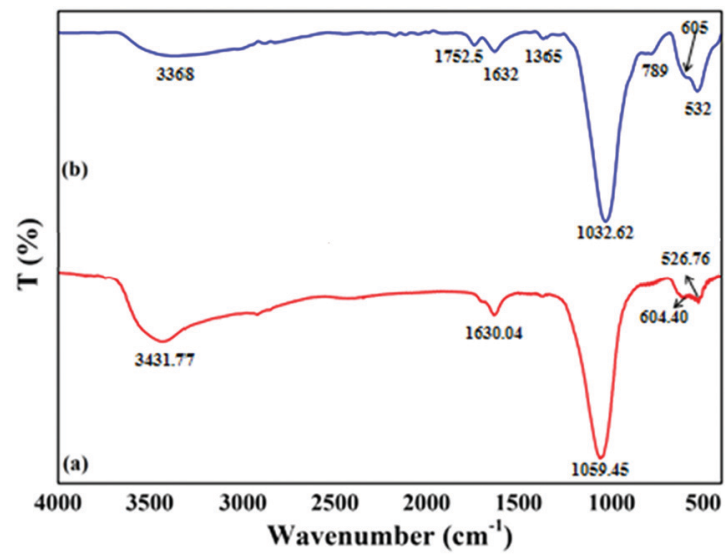

Fig. 2 FTIR spectra of (a) SnZrMoP and (b) GAgNPs-SnZrMoP nanocomposite.

and asymmetric -OH streching. The absorption band at $1630.04 \mathrm{~cm}^{-1}$ was due to the $\mathrm{H}-\mathrm{O}-\mathrm{H}$ bending of interstitial water in the composite material. A band in the region of $1059.45 \mathrm{~cm}^{-1}$ corresponded to ionic phosphate stretching. The band at $\sim 526.75 \mathrm{~cm}^{-1}$ was attributed to the $\mathrm{Zr}-\mathrm{O}$ bond. A sharp peak at $601.40 \mathrm{~cm}^{-1}$ was ascribed to the presence of a molybdate group. ${ }^{28}$ The FTIR spectrum of the GAgNPsSnZrMoP (Fig. 2b) showed a broad band in the region of $3368 \mathrm{~cm}^{-1}$, which could be attributed to symmetric and asymmetric - $\mathrm{OH}$ stretching, and this peak may be due to the presence of alcohols and phenols in the plant extract. The peak at $1752 \mathrm{~cm}^{-1}$ indicated the stretching vibrations of $\mathrm{C}=\mathrm{O}$ group. The band at $1632 \mathrm{~cm}^{-1}$ was attributed to $\mathrm{N}-\mathrm{H}$ bending vibrations of primary amines. The band at $1365 \mathrm{~cm}^{-1}$ corresponded to the $\mathrm{C}-\mathrm{N}$ streching of aromatic ring compounds. The broad band at $1051 \mathrm{~cm}^{-1}$ may be due to the presence of $\mathrm{PO}_{4}{ }^{3-}, \mathrm{HPO}_{4}{ }^{-}$, and $\mathrm{H}_{2} \mathrm{PO}_{4}{ }^{4-}$ groups. The band at $\sim 532 \mathrm{~cm}^{-1}$ may be due to the presence of $\mathrm{Zr}-\mathrm{O}$ bond and $\mathrm{Sn}-\mathrm{O}$ bond. The sharp peak at $605 \mathrm{~cm}^{-1}$ was attributed to the molybdate group. The appearance of three new bands at 1752,1365 , and $789 \mathrm{~cm}^{-1}$ may be due to the incorporation of green silver nanoparticles in the hybrid material. The variation in the wave numbers of different peaks may also be due to the embedding of silver nanoparticles into the tetravalent metal acid salt.

The X-ray diffraction pattern of the SnZrMoP ion exchanger showed characteristic peaks that match the JCPDS card number 00-024-1491, indicating the semicrystalline nature of the ion exchanger (Fig. 3a). The XRD spectrum of GAgNPs (Fig. 3b) showed four characteristic diffraction peaks at $2 \theta$ of 28.21 (111), 42.73 (200), 64.54 (220), and 76.63 (311). This pattern matches with JCPDS card number 89-3722, and corresponds to the fcc lattice of silver. ${ }^{29}$ The XRD pattern of GAgNPs depicted its crystalline nature. The variations in the intensities of different peaks may be due to the presence of organic compounds in the plant extracts. The XRD pattern of the nanocomposite material GAgNPs-SnZrMoP (Fig. 3c) revealed its polycrystalline nature. The appearance of characteristic diffraction peaks at $2 \theta$ of 28.01 (111), 46.44 (200), and 66.54 (220) clearly demonstrated the incorporation of GAgNPs into the inorganic ion-exchanger. 


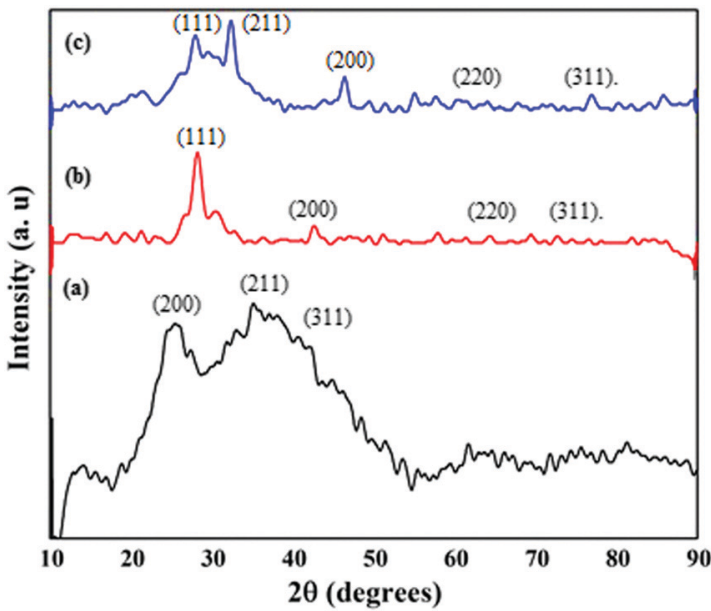

Fig. 3 X-ray diffraction patterns of (a) SnZrMoP; (b) GAgNPs; (c) GAgNPsSnZrMoP nanocomposite.

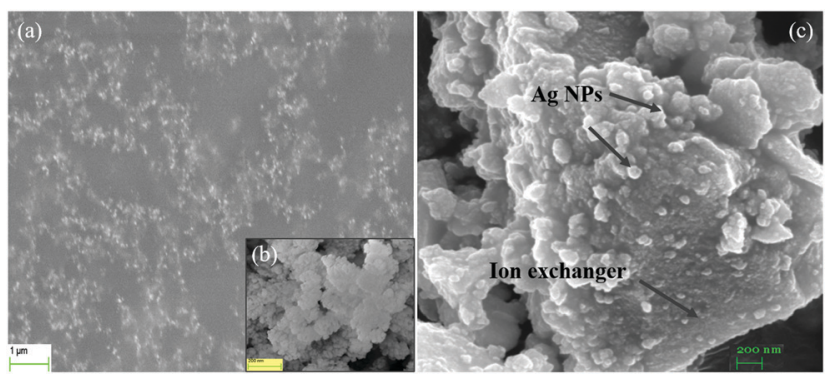

Fig. 4 FESEM images of (a) GAgNPs; (b) SnZrMoP; (c) GAgNPs-SnZrMoP nanocomposite.

The FESEM image (Fig. 4a) of the GAgNPs revealed that the particles were spherical in shape and agglomerated. The FESEM image of SnZrMoP (Fig. 4b) revealed that the inorganic ion-exchanger contained globular particles and there were areas of aggregations and agglomerations. The surface morphology of the nanocomposite material revealed that the material contained aggregates of silver nanoparticles, which were uniformly embedded in the matrix of the inorganic ion exchanger SnZrMoP (Fig. 4c).

The typical HRTEM images (Fig. 5a and b) revealed that the biogenic silver nanoparticles were spherical in shape. These nanoparticles were lying apart due to the reduction and capping

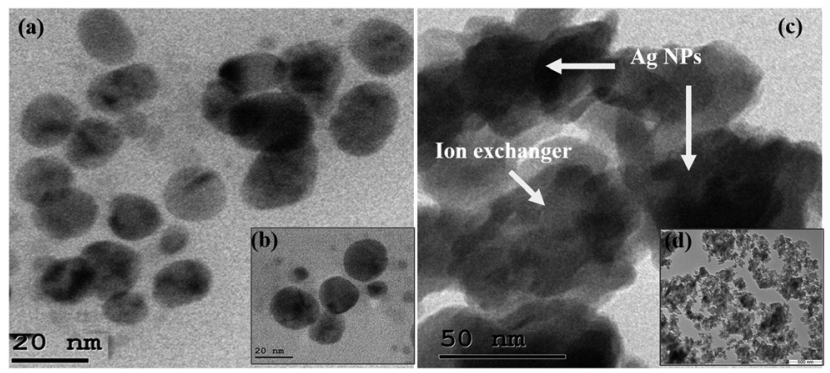

Fig. 5 HRTEM images of (a and b) GAgNPs; (c) GAgNPs-SnZrMoP nanocomposite; and (d) SnZrMoP ion-exchanger.

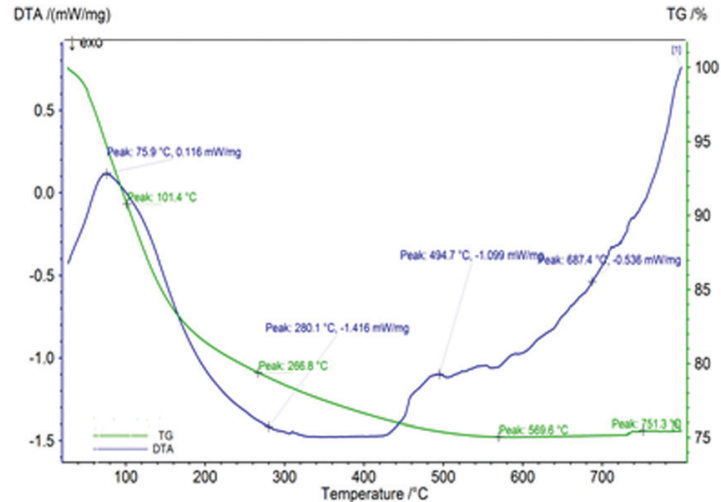

Fig. 6 TGA-DTA curves of the GAgNPs-SnZrMoP nanocomposite ion exchanger.

of silver nanoparticles with the phytochemicals present in the mulberry leaf extract. The average particle size of the GAgNPs was $\approx 15 \mathrm{~nm}$, which was in good agreement with the particle size calculated from the XRD analysis. It could be observed from the images in Fig. 5d that the inorganic material was composed of a network of nearly spherical particles. It is clear from the HRTEM images of the synthesized AgNPs-SnZrMoP composite (Fig. 5c) that a large number of well-dispersed AgNPs were attached to the surface of the ion exchanger.

TGA/DTA studies of the GAgNPs-SnZrMoP nanocomposite hybrid ion exchanger are shown in Fig. 6. The nanocomposite exchanger was heated from room temperature to $800{ }^{\circ} \mathrm{C}$, with an increment of $10{ }^{\circ} \mathrm{C} \mathrm{min}^{-1}$. The weight loss up to $101{ }^{\circ} \mathrm{C}$ was $\approx 8.99 \%$, which was due to loss of water molecules from the sample. This change was confirmed from the endothermic hump in the same region of the DTA curve. The weight loss in the $101-266{ }^{\circ} \mathrm{C}$ temperature range was $\approx 11 \%$, which was due to the loss of the water of crystallization. The weight loss in the temperature range $266-569{ }^{\circ} \mathrm{C}$ was $\approx 4.75 \%$, which was due to the conversion of inorganic phosphate into pyrophosphate. ${ }^{30}$ There was no significant weight loss in the temperature range 594.7-800 ${ }^{\circ} \mathrm{C}$ which established high thermal stability of the nanocomposite material.

\section{Physiochemical properties}

The ion-exchange capacity of alkali metals and alkaline earth metals follows the order: $\mathrm{K}^{+}>\mathrm{Na}^{+}>\mathrm{Li}^{+}$and $\mathrm{Ba}^{2+}>\mathrm{Sr}^{2+}>$ $\mathrm{Ca}^{2+}>\mathrm{Mg}^{2+}$, respectively (Table 2). The decrease in ion-exchange capacity of both the alkali and alkaline earth metals is in accordance

Table 2 IEC of the GAgNPs-SnZrMoP nanocomposite for alkali and alkaline earth metals

\begin{tabular}{lllll}
\hline S. no. & $\begin{array}{l}\text { Exchanging } \\
\text { ion }\end{array}$ & $\begin{array}{l}\text { Ionic } \\
\text { radii }(\AA)\end{array}$ & $\begin{array}{l}\text { Hydrated } \\
\text { ionic radii }(\AA)\end{array}$ & $\begin{array}{l}\text { IEC } \\
\left(\mathrm{meq} \mathrm{g}^{-1}\right)\end{array}$ \\
\hline 1 & $\mathrm{Li}^{+}$ & 0.68 & 3.40 & 2.42 \\
2 & $\mathrm{Na}^{+}$ & 0.97 & 2.76 & 2.48 \\
3 & $\mathrm{~K}^{+}$ & 1.33 & 2.32 & 2.55 \\
4 & $\mathrm{Mg}^{2+}$ & 0.78 & 10.80 & 2.62 \\
5 & $\mathrm{Ca}^{2+}$ & 1.06 & 9.60 & 2.73 \\
6 & $\mathrm{Sr}^{2+}$ & 1.27 & 6.30 & 2.80 \\
7 & $\mathrm{Ba}^{2+}$ & 1.43 & 5.90 & 2.89
\end{tabular}



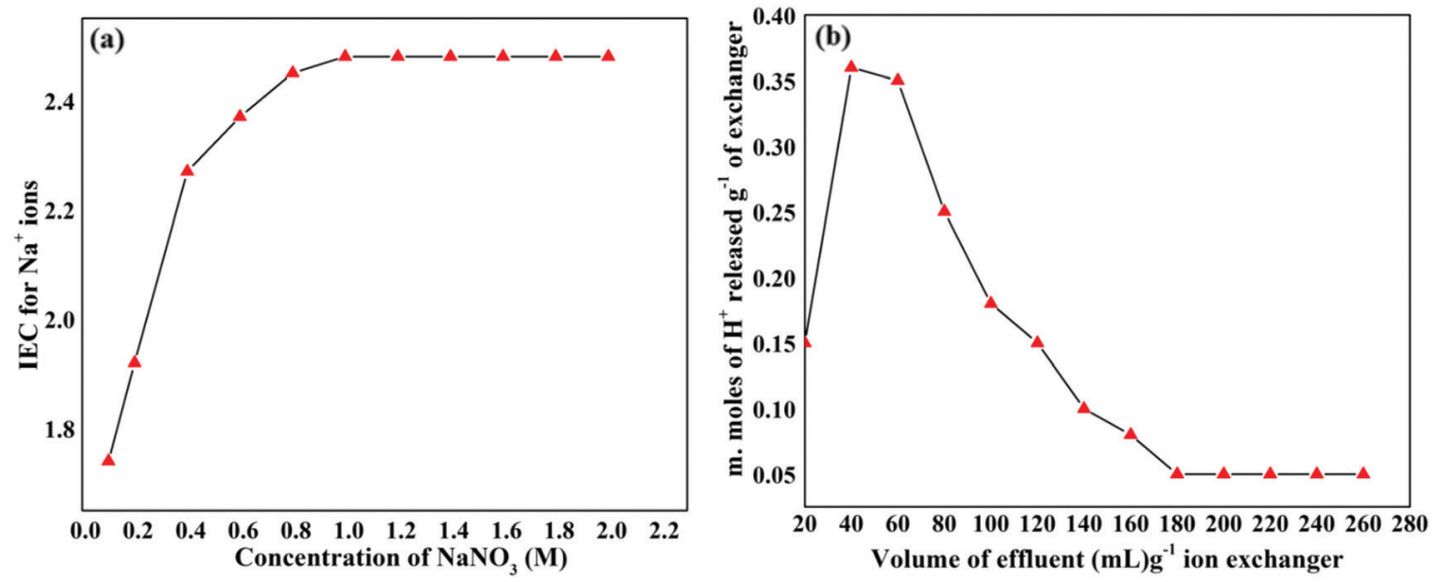

Fig. 7 (a) Effect of the eluent concentration; (b) elution behavior of the GAgNPs-SnZrMoP nanocomposite ion exchanger.

with decrease in their hydrated ionic radii. Coulomb's law is obeyed by ionic crystals, according to which a small cation will be attracted with a greater force and held more strongly than a bigger ion of the same charge. Also, ions having smaller hydrated ionic radii can easily penetrate into the pores of the exchanger and interact with the active sites for the exchange of $\mathrm{H}^{+}$ions, resulting in a higher ion-exchange capacity. ${ }^{24}$

The effect of eluent concentration on the ion-exchange capacity of the GAgNPs-SnZrMoP nanocomposite is shown in Fig. 7(a). It was observed that the degree of elution also depended on the concentration of the eluent. The optimum concentration of $\mathrm{NaNO}_{3}$ as an eluent was observed to be $0.8 \mathrm{M}$ for $1.0 \mathrm{~g}$ of the cation exchanger. The column elution experiment reflected the column efficiency and predicts the volume of eluent required for the complete elution of $\mathrm{H}^{+}$ions. It was observed from the elution behavior that the exchange rate is faster in the beginning and a maximum of $\mathrm{H}^{+}$ions were eluted in the first $150 \mathrm{~mL}$ of $\mathrm{NaNO}_{3}$ solution $(1 \mathrm{M})$. It was observed that about $250 \mathrm{~mL}$ of $\mathrm{NaNO}_{3}$ solution $(1 \mathrm{M})$ was sufficient to elute all the exchangeable $\mathrm{H}^{+}$ions from $500 \mathrm{mg}$ of the sample in $\sim 4 \mathrm{~h}$ (Fig. $7 \mathrm{~b}$ ).

The ion-exchange capacity of the nanocomposite was also affected by calcination (Table 3). The nanocomposite was heated in the temperature range of $100{ }^{\circ} \mathrm{C}$ to $800{ }^{\circ} \mathrm{C}$ for $1 \mathrm{~h}$.

It was observed that there was a significant decrease in the ion-exchange capacity of the nanocomposite cation exchanger at higher temperature, which might be due to the condensation of phosphate groups to pyrophosphate at elevated temperature.
However, the ion exchanger was found to be quite stable to heat as the composite retained about $86.28 \%$ of its mass and $85.50 \%$ of its ion-exchange capacity up to a temperature of $300{ }^{\circ} \mathrm{C}$.

It was observed that the nanocomposite had a reasonably good stability in different solvents. The chemical stability may be due to the binding of GAgNPs with the inorganic matrix. This can prevent the dissolution of the nanohybrid material or the leaching of any of its constituent elements in the solution. The GAgNPs-SnZrMoP was resistant to dissolution even in $1 \mathrm{M}$ $\mathrm{HNO}_{3}$ solution. The material showed negligible dissolution in organic solvents, while very feeble dissolution was observed in alkaline medium, which overall shows that the material exhibited good chemical stability (Table 4).

Distribution studies were performed for 15 different metal ions in diverse solvent systems to explore the potential of the nanocomposite for the separation of metal ions. It was observed that the $K_{\mathrm{d}}$ values varied with the nature of the solvent. It was also observed (Table 5) that $\mathrm{Ba}^{2+}$ was strongly adsorbed, and $\mathrm{Sr}^{2+}$, $\mathrm{Pb}^{2+}$, and $\mathrm{Hg}^{2+}$ were significantly adsorbed, while other metal ions were poorly adsorbed on the surface of the nanocomposite.

Some analytically important binary separations were performed on the basis of the separation factors, such as: $\mathrm{Cu}(\mathrm{II})-\mathrm{Ba}(\mathrm{II}) ; \mathrm{Ca}(\mathrm{II})-$ $\mathrm{Ba}(\mathrm{II}) ; \mathrm{Mg}(\mathrm{II})-\mathrm{Ba}(\mathrm{II}) ; \mathrm{Fe}$ (III)-Ba(II); $\mathrm{Ni}(\mathrm{II})-\mathrm{Ba}(\mathrm{II}) ; \mathrm{Hg}(\mathrm{II})-\mathrm{Ba}(\mathrm{II})$. The order of elution and the eluents used for the binary separations are given in Table 6.

During the separation of $\mathrm{Ba}^{2+}$ ions from the synthetic mixtures of different metal ions, nearly more than $90 \%$ of

Table 3 Effect of temperature on the ion-exchange capacity of the GAgNPs-SnZrMoP nanocomposite

\begin{tabular}{|c|c|c|c|c|c|}
\hline S. no. & Heating temp. $\left({ }^{\circ} \mathrm{C}\right)$ & Color of granules & Weight retained (\%) & $\begin{array}{l}\text { IEC for } \mathrm{Na}^{+} \\
\text {ions }\left(\mathrm{meq} \mathrm{g}^{-1}\right)\end{array}$ & $\begin{array}{l}\text { Retained ion-exchange } \\
\text { capacity }(\%)\end{array}$ \\
\hline 1 & 50 & Shiny grey & 99.60 & 2.40 & 100 \\
\hline 2 & 100 & Blackish brown & 94.12 & 2.30 & 97.56 \\
\hline 4 & 300 & Black grey & 86.28 & 1.50 & 85.50 \\
\hline 5 & 400 & Dark grey & 78.43 & 1.45 & 82.40 \\
\hline 6 & 500 & Silvery grey & 64.71 & 1.20 & 70.00 \\
\hline 9 & 800 & Silvery grey & 66.67 & 0.85 & 36.32 \\
\hline
\end{tabular}


Table 4 Chemical stability of the GAgNPs-SnZrMoP nanocomposite ion exchanger

\begin{tabular}{|c|c|c|c|c|c|c|}
\hline S. no. & Solvent & Mass loaded (mg) & Mass retained (mg) & Mass retained (\%) & Color & $\begin{array}{l}\text { IEC for } \mathrm{Na}^{+} \text {ions } \\
\left(\mathrm{meq}^{-1}\right)\end{array}$ \\
\hline 1 & $1 \mathrm{M} \mathrm{HNO}_{3}$ & 200 & 200 & 98.80 & Shiny grey & 2.45 \\
\hline 2 & $1 \mathrm{M} \mathrm{HCl}$ & 200 & 198 & 99.20 & Shiny grey & 2.46 \\
\hline 3 & $1 \mathrm{M} \mathrm{H}_{2} \mathrm{SO}_{4}$ & 200 & 198 & 98.80 & Shiny grey & 2.45 \\
\hline 4 & $1 \mathrm{M} \mathrm{NaOH}$ & 200 & 127 & 68.55 & Shiny grey & 1.70 \\
\hline 5 & $5 \%$ Acetone & 200 & 200 & 100 & Shiny grey & 2.48 \\
\hline 6 & $5 \%$ Ethanol & 200 & 196 & 99.20 & Shiny grey & 2.46 \\
\hline
\end{tabular}

Table $5 \quad K_{d}$ values of some metal ions on the GAgNPs-SnZrMoP nanohybrid ion-exchanger column in different solvent systems

\begin{tabular}{lllll}
\hline Metal ions & DMW & $0.1 \mathrm{M} \mathrm{CH}_{3} \mathrm{COOH}$ & $0.1 \mathrm{M} \mathrm{HNO}_{3}$ & $0.5 \mathrm{M} \mathrm{HNO}_{3}$ \\
\hline $\mathrm{Mg}^{2+}$ & 29.50 & 22.71 & 19.61 & 13.57 \\
$\mathrm{Ca}^{2+}$ & 64.94 & 47.08 & 39.65 & 29.22 \\
$\mathrm{Sr}^{2+}$ & 890 & 627.18 & 548.77 & 268.69 \\
$\mathrm{Ba}^{2+}$ & 1640 & 1399 & 1179 & 770 \\
$\mathrm{Cr}^{3+}$ & 210 & 166.32 & 152 & 98.64 \\
$\mathrm{Fe}^{3+}$ & 64.67 & 51.22 & 45.94 & 32.05 \\
$\mathrm{Co}^{2+}$ & 5.71 & 4.80 & 4.33 & 1.97 \\
$\mathrm{Ni}^{2+}$ & 14.00 & 10.64 & 10.36 & 5.58 \\
$\mathrm{Cu}^{2+}$ & 29.13 & 22.48 & 21.86 & 11.00 \\
$\mathrm{Zn}^{2+}$ & 66.40 & 54.86 & 41.71 & 19.88 \\
$\mathrm{Cd}^{2+}$ & 54.84 & 41.13 & 22.32 & 13.33 \\
$\mathrm{Hg}^{2+}$ & 400 & 349.32 & 326.68 & 198.80 \\
$\mathrm{~Pb}^{2+}$ & 550 & 469 & 396.55 & 198.83 \\
$\mathrm{Al}^{3+}$ & 9.73 & 8.21 & 6.99 & 1.65 \\
& & & &
\end{tabular}

the metal ions were recovered successfully. The percentage recovery of $\mathrm{Ba}^{2+}$ ions remained almost constant (>88\%) upon increasing the loading of $\mathrm{Ba}^{2+}$ ions (Table 7). These results confirm the high efficiency of the GAgNPs-SnZrMoP nanocomposite column.
Set 1: $\mathrm{Ba}^{2+}(1.37 \mathrm{mg}), \mathrm{Co}^{2+}(0.59 \mathrm{mg}), \mathrm{Ni}^{2+}(0.58 \mathrm{mg}), \mathrm{Ca}^{2+}$ $(0.20 \mathrm{mg}), \mathrm{Mg}^{2+}(0.24 \mathrm{mg}), \mathrm{Fe}^{3+}(0.56 \mathrm{mg})$.

Set 2: $\mathrm{Ba}^{2+}(2.74 \mathrm{mg})$ and the amounts of rest of metals were kept same as in Set 1 .

Set 3: $\mathrm{Ba}^{2+}(4.11 \mathrm{mg})$ and the amounts of rest of metals were kept same as in Set 1 .

Similarly, the selective separation of $\mathrm{Sr}^{2+}$ ions was achieved on the column of GAgNPs-SnZrMoP, from the following binary synthetic mixtures of metal ions: $\mathrm{Ca}(\mathrm{II})-\mathrm{Sr}(\mathrm{II})$; $\mathrm{Mg}$ (II)-Sr(II); $\mathrm{Co}(\mathrm{II})-\mathrm{Sr}(\mathrm{II}) ; \mathrm{Cu}(\mathrm{II})-\mathrm{Sr}(\mathrm{II})$; $\mathrm{Ni}(\mathrm{II})-\mathrm{Sr}(\mathrm{II})$, and the recovery of $\mathrm{Sr}(\mathrm{II})$ was more than $89 \%$ (Table 8 ).

Set 1: $\mathrm{Sr}^{2+}(0.59 \mathrm{mg}), \mathrm{Zn}^{2+}(0.65 \mathrm{mg}), \mathrm{Ni}^{2+}(0.58 \mathrm{mg}), \mathrm{Mg}^{2+}$ (0.24 mg), $\mathrm{Cu}^{2+}(0.63 \mathrm{mg})$.

Set 2: $\mathrm{Sr}^{2+}(1.18 \mathrm{mg})$, and the amounts of rest of metals were kept same as in Set 1 .

Set 3: $\mathrm{Sr}^{2+}(1.77 \mathrm{mg})$, and the amounts of rest of metals were kept same as in Set 1 .

\section{Applications}

Removal of $\mathrm{Ba}(\mathrm{II})$ ions from wastewater samples. From the above observations, it is evident that the synthesized material is

Table 6 Quantitative separation of metal ions from binary mixtures using the GAgNPs-SnZrMoP column

\begin{tabular}{|c|c|c|c|c|c|c|c|c|}
\hline & Senarations & Separation factor & Eluent used & \multicolumn{2}{|c|}{ Metal ions (mg) } & Efficiency (\%) & Error (\%) & $\begin{array}{l}\text { Volume of eluent } \\
\text { required }(\mathrm{mL})\end{array}$ \\
\hline \multirow[t]{9}{*}{ GAgNPs-SnZrMoP } & $\mathrm{Cu}(\mathrm{II})$ & 56.30 & $0.1 \mathrm{M} \mathrm{HNO}_{3}$ & 2.35 & 2.15 & 91.49 & -8.51 & 60 \\
\hline & $\mathrm{Ca}(\mathrm{II})$ & 25.25 & $0.1 \mathrm{M} \mathrm{HNO}_{3}$ & 2.16 & 1.78 & 82.40 & -17.6 & 60 \\
\hline & $\mathrm{Ba}$ (II) & & $0.5 \mathrm{M} \mathrm{HNO}_{3}$ & 22.52 & 20.64 & 91.65 & -8.35 & 40 \\
\hline & $\operatorname{Mg}(\mathrm{II})$ & 55.59 & $0.1 \mathrm{M} \mathrm{HNO}_{3}$ & 1.31 & 1.23 & 93.89 & -6.11 & 40 \\
\hline & $\mathrm{Ba}$ (II) & & $0.5 \mathrm{M} \mathrm{HNO}_{3}$ & 22.52 & 20.46 & 90.85 & -9.15 & 60 \\
\hline & $\mathrm{Ni}(\mathrm{II})$ & 117.14 & $0.1 \mathrm{M} \mathrm{HNO}_{3}$ & 1.64 & 1.46 & 89.02 & -10.98 & 40 \\
\hline & $\mathrm{Ba}(\mathrm{II})$ & & $0.5 \mathrm{M} \mathrm{HNO}_{3}$ & 22.52 & 20.60 & 91.47 & -8.53 & 60 \\
\hline & $\mathrm{Hg}$ (III) & 26.35 & $0.1 \mathrm{M} \mathrm{HNO}_{3}$ & 16.04 & 14.10 & 87.91 & -12.09 & 60 \\
\hline & $\mathrm{Ba}(\mathrm{II})$ & & $0.5 \mathrm{M} \mathrm{HNO}_{3}$ & 22.52 & 20.25 & 89.92 & -10.08 & 60 \\
\hline
\end{tabular}

${ }^{a}$ An average of three replicate determinations.

Table 7 Selective separation of $\mathrm{Ba}^{2+}$ from a synthetic mixture of $\mathrm{Ba}^{2+}, \mathrm{Co}^{2+}, \mathrm{Ni}^{2+}, \mathrm{Ca}^{2+}, \mathrm{Mg}^{2+}$, and $\mathrm{Fe}^{3+}$ ions on the column of $\mathrm{GAgNPs}-\mathrm{SnZ} \mathrm{M} M \mathrm{P}$

\begin{tabular}{|c|c|c|c|c|c|c|c|}
\hline \multirow[t]{2}{*}{$\mathrm{Ba}^{2+}$} & 1 & 1.37 & 1.21 & 88.32 & -11.68 & 60 & $0.5 \mathrm{M} \mathrm{HNO}_{3}$ \\
\hline & 3 & 4.11 & 3.684 & 89.54 & -10.46 & 60 & $0.5 \mathrm{M} \mathrm{HNO}_{3}$ \\
\hline
\end{tabular}

${ }^{a}$ Average of three replicate determinations. 
Table 8 Selective separation of $\mathrm{Sr}^{2+}$ ions from a synthetic mixture of $\mathrm{Ca}^{2+}, \mathrm{Mg}^{2+}, \mathrm{Co}^{2+}, \mathrm{Cu}^{2+}$, and $\mathrm{Ni}^{2+}$ ions on the column of $\mathrm{GAgNPs}-\mathrm{SnZrMoP}$

\begin{tabular}{|c|c|c|c|c|c|c|c|}
\hline Metal ions & Set no. & $\begin{array}{l}\text { Amount } \\
\text { loaded (mg) }\end{array}$ & $\begin{array}{l}\text { Amount } \\
\text { recovered }^{a}(\mathrm{mg})\end{array}$ & Recovery (\%) & Error (\%) & $\begin{array}{l}\text { Volume of } \\
\text { eluent used }(\mathrm{mL})\end{array}$ & Eluent used \\
\hline \multirow[t]{2}{*}{$\overline{\mathrm{Sr}^{2+}}$} & 1 & 0.59 & 0.53 & 89.83 & -10.17 & 60 & $0.5 \mathrm{M} \mathrm{HNO}_{3}$ \\
\hline & 2 & 1.18 & 1.07 & 90.67 & -9.33 & 60 & $0.5 \mathrm{M} \mathrm{HNO}_{3}$ \\
\hline
\end{tabular}

${ }^{a}$ Average of three replicate determinations.

Table 9 Separation of $\mathrm{Ba}^{2+}$ ions from wastewater samples collected from glass, paint, and brick-making industries, and a chemistry lab on a column of the GAgNPs-SnZrMoP nanocomposite

\begin{tabular}{|c|c|c|c|c|c|}
\hline Glass industry & $\mathrm{Ba}^{2+}$ & $0.5 \mathrm{M} \mathrm{HNO}_{3}$ & 1.62 & 1.45 & 89.50 \\
\hline Brick-making industry & & $0.5 \mathrm{M} \mathrm{HNO}_{3}$ & 1.73 & 1.56 & 90.17 \\
\hline Chemistry laboratory & & $0.5 \mathrm{M} \mathrm{HNO}_{3}$ & 0.85 & 0.75 & 88.24 \\
\hline
\end{tabular}
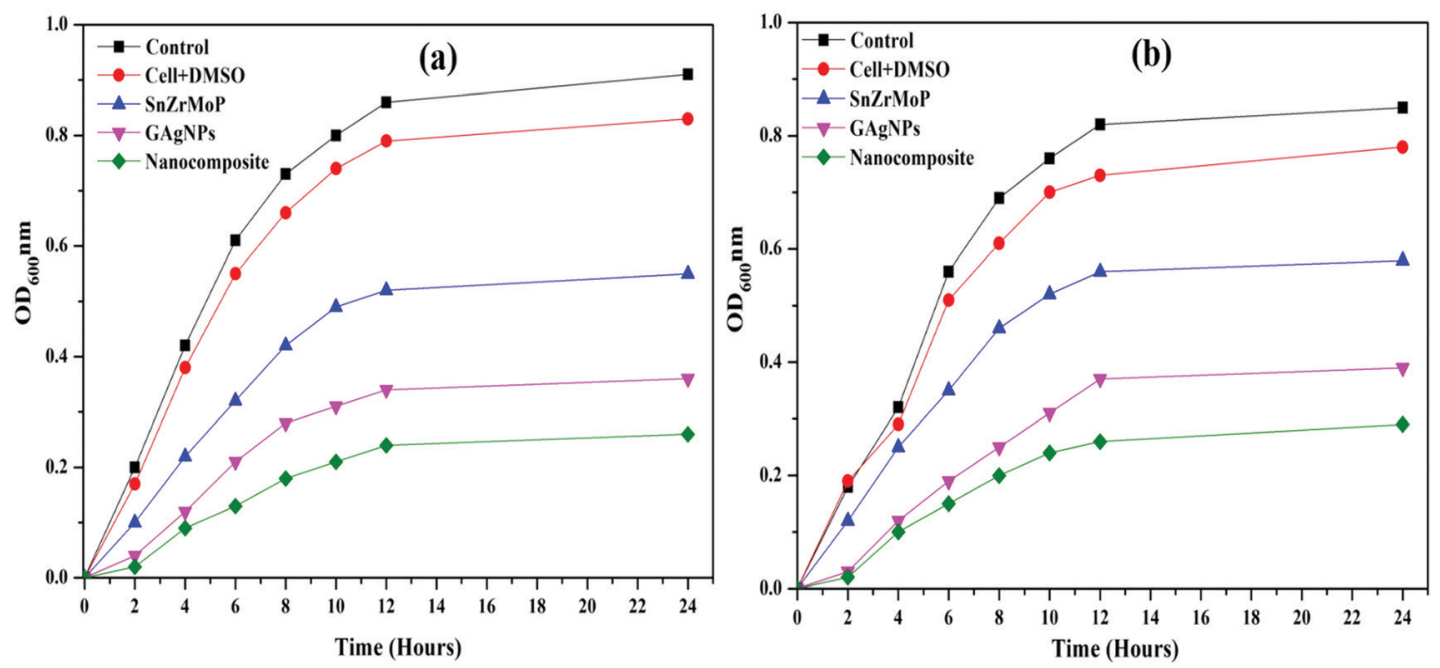

Fig. 8 Growth curves of (a) E. coli; (b) Bacillus bacteria.

an efficient candidate for the effective removal of $\mathrm{Ba}^{2+}$ ions from wastewater samples collected from different sources. The nanocomposite was used for the removal of $\mathrm{Ba}(\mathrm{II})$ ions from wastewater samples collected from different industrial units. The $\mathrm{Ba}^{2+}$ ions were quantitatively separated and recovered from wastewater containing $1.45,1.38,1.56$, and $0.75 \mathrm{mg}$ of $\mathrm{Ba}(\mathrm{II})$ ions in effluents obtained from glass, paint, and brick-making industries, and from a chemistry lab, respectively (Table 9).

\section{Antimicrobial study}

It was revealed from the antibactetal studies that all three materials inhibited the growth of both $\mathrm{G}^{+}$and $\mathrm{G}^{-}$bacterial cultures to an astonishing level in the order: GAgNPs-SnZrMoP > GAgNPs > SnZrMoP. However, both the bacteria showed regular growth under the control experiment conditions (Fig. 8). The inhibition in the growth of both $\mathrm{G}^{+}$and $\mathrm{G}^{-}$bacterial cultures might be due to strong interactions of the nanocomposite with the cell membrane due to which the cellular and molecular functions of the cell are interrupted by interfering with its permeability. This may finally result in a crumbling of the layer structure that ultimately causes the death of the cells. ${ }^{31}$

\section{Conclusion}

In the present study, a $\mathrm{Ba}$ (II) selective nanocomposite cation exchanger GAgNPs-tin zirconium(Iv) molybdophosphate was synthesized by a sol-gel method, which had a good ion-exchange capacity $\left(2.48 \mathrm{meq}^{-1}\right)$ as compared to its inorganic counterpart tin-zirconium(Iv) molybdophosphate $\left(1.95 \mathrm{meq} \mathrm{g}^{-1}\right)$. From the HR-TEM, interactions between the green silver nanoparticles and polybasic acid salt (tin-zirconium molybdophosphate) are very clear and are responsible for its high thermal and chemical stability. It is clear that the particle sizes were in the range of $10-20 \mathrm{~nm}$. The nanohybrid cation exchanger, GAgNPs-SnZrMoP 
was successfully used for inhibition of the growth of both bacterial cultures, i.e., E. coli (Gram (-) ve) and Bacillus (Gram $(+)$ ve). The nanohybrid cation exchanger, GAgNPs-SnZrMoP had better antibacterial properties as compared to the inorganic ion exchanger (SnZrMoP) and metal nanoparticles (GAgNPs). On the basis of distribution coefficient studies, some analytically important binary separations were also performed. The recovery of metal ions was very sharp, and more than $88 \%$ of metals was recovered successfully. On the basis of the above results, it can be concluded that the nanocomposite ion exchanger GAgNPsSnZrMoP can be used as an efficient candidate for environmental remedation.

\section{Conflicts of interest}

There are no conflicts to declare.

\section{Acknowledgements}

The authors gratefully acknowledge Sri Guru Granth Sahib World University, Fatehgarh Sahib, Punjab (India) and Guru Nanak Dev Polytechnic College, Ludhiana (India) for providing the necessary facilities.

\section{References}

1 M. Sekar, V. Sakthi and S. Rengaraj, Kinetics and equilibrium adsorption study of lead(II) onto activated carbon prepared from coconut shell, J. Colloid Interface Sci., 2004, 279, 307-313.

2 I. A. Jaccob, J. Taddeo, K. Kelly and C. Valenziano, Poisoning as a result of barium styphnate explosion, Am. J. Ind. Med., 2002, 41(4), 285-288.

3 D. W. Stewart and R. P. Hummel, Acute poisoning by barium chloride bum, J. Trauma, 1984, 24(8), 768-770.

4 S. Ananda, Z. Shaohua and L. Liang, Fatal barium chloride poisoning: four cases report and literature review, Am. Forensic Med. Pathol., 2013, 34(2), 115-118.

5 S. H. Rhyee and K. Heard, Acute barium toxicity from ingestion of "snake" fire work, J. Med. Toxicol., 2009, 5(4), 2009-2013.

6 Y. H. Ma, R. Yuan, Y. Q. Chai and X. L. Liu, A highly selective polymeric membrane barium(II) electrode based on a macrocyclic tetrabasic ligand as neutral carrier, Anal. Bioanal. Chem., 2009, 395, 855-862.

7 C. T. Hsieh, C. Y. Lina, Y. F. Chen, J. S. Lin and H. Teng, Silver nanorods attached to graphene sheets as anode materials for lithium-ion batteries, Carbon, 2013, 62, 109-116.

8 H. Teddy, F. Katia, E. David, C. Vincent, B. Philippe and G. Pierre, Gold nanoparticles electrodeposited on glassy carbon using cyclic voltammetry: Application to $\mathrm{Hg}$ (II) trace analysis, J. Electroanal. Chem., 2012, 664, 46-52.

9 E. Sterling, J. Stolk and L. Hafford, et al., Sodium Borohydride Reduction of Aqueous Silver-Iron-Nickel Solutions: a Chemical Route to Synthesis of Low Thermal Expansion-High Conductivity Ag-Invar Alloys, Metall. Mater. Trans. A, 2009, 40, 1701-1709.
10 J. Selvamuthumari, S. Meenakshi, M. Ganesan, S. Nagaraj and K. Pandian, Antibacterial and catalytic properties of silver nanoparticles loaded zeolite: green method for synthesis of silver nanoparticles using lemon juice as reducing agent, Nanosyst.: Phys. Chem., Math., 2016, 7(4), 768-773.

11 J. R. Nakkala, R. Mata, A. K. Gupta and S. R. Sadras, Biological activities of green silver nanoparticles synthesized with Acorouscalamus rhizome extract, Eur. J. Med. Chem., 2014, 85, 784-794.

12 S. Ahmed, M. Ahmad, B. L. Swami and S. Ikram, A review on plants extract mediated synthesis of silver nanoparticles for antimicrobial applications: A green expertise, J. Adv. Res., 2016, 7, 17-28.

13 P. Sathishkumar, K. Vennila, R. Jayakumar, A. R. M. Yusoff, T. Hadibarata and T. Palvannan, Phyto-synthesis of silver nanoparticles using Alternantheratenella leaf extract: An effective inhibitor for the migration of human breast adenocarcinoma (MCF-7) cells, Bioproc, Biosyst. Eng., 2016, 39(4), 651-659.

14 G. Singhal, R. Bhavesh, K. Kasariya, A. R. Sharma and R. P. Singh, Biosynthesis of silver nanoparticles using Ocimum sanctum (Tulsi) leaf extract and screening its antimicrobial activity, J. Nanopart. Res., 2011, 13(7), 2981-2988.

15 S. Ahmed, M. Ahmad, B. L. Swami and S. Ikram, Green synthesis of silver nanoparticles using Azadirachtaindica aqueous leaf extract, J. Radiat Res. Appl. Sci., 2016, 9(1), 1-7.

16 K. B. Narayanan and H. H. Park, Antifungal activity of silver nanoparticles synthesized using turnip leaf extract (Brassica rapa L.) against wood rotting pathogens, Eur. J. Plant Pathol., 2014, 140(2), 185-192.

17 R. Arunachalam, S. Dhanasingh, B. Kalimuthu, M. Uthirappan, C. Rose and A. B. Mandal, Phytosynthesis of silver nanoparticles using Cocciniagrandis leaf extract and its application in the photocatalytic degradation, Colloids Surf., B, 2012, 94, 226-230.

18 M. Zargar, K. Shameli, G. R. Najafi and F. Farahani, Plant mediated green biosynthesis of silver nanoparticles using Vitex negundo L. extract, J. Ind. Eng. Chem., 2014, 20(6), 4169-4175.

19 M. Amin, F. Anwar, M. Janjua, M. Iqbal and U. Rashid, Green Synthesis of Silver Nanoparticles through Reduction with Solanumxanthocarpum L. Berry Extract: Characterization, Antimicrobial and Urease Inhibitory Activities against Helicobacter pylori, Int. J. Mol. Sci., 2012, 13, 9923-9941.

20 K. Khanra, S. Panja, I. Choudhuri, A. Chakraborty and N. Bhattacharyya, Antimicrobial and cytotoxicity effect of silver nanoparticle synthesized by Croton Bon plandianum Baill. Leaves, Nanomed. J., 2016, 3(1), 15-22.

21 G. Yunlong, W. Bin, Y. M. Liu, Y. Ying, J. Zheng and G. Y. Liu, Electrical Assembly and Reduction of Graphene Oxide in a Single Solution Step for Use in Flexible Sensors, Adv. Mater., 2011, 40, 4626-4630.

22 J. Li, D. Kuang, Y. Feng, F. Zhang, Z. Xu and M. Liu, A graphene oxide-based electrochemical sensor for sensitive determination of 4-nitrophenol, J. Hazard. Mater., 2012, 201, 250-259. 
23 S. Kaushal, R. Badru, P. Singh, S. Kumar and S. K. Mittal, Nano composite Zirconium phosphoborate incorporated with carbon nano tubes Ion-exchanger with Photocatalytic Activity, Sep. Sci. Technol., 2016, 51(18), 2896-2902.

24 S. Kaushal, P. K. Sharma, S. K. Mittal and P. Singh, A Novel Zinc Oxide-Zirconium(Iv) Phosphate Nano-composite as Anti-bacterial Material with Enhanced Ion Exchange Properties, J. Colloids Interface Sci. Commun., 2015, 7, 1-6.

25 P. VinishaValsaraj and C. Janardanan, Separation of Toxic Metal Ions Such as $\mathrm{Pb}$ (II), $\mathrm{Cu}$ (II) and $\mathrm{Hg}$ (II) from Industrial Waste Water Using Newly Synthesisedtinzirconiummolybdophosphate Cation Exchanger, J. Environ. Nanotechnol., 2013, 2, 6-14.

26 G. Sharma and D. Pathania, Fabrication, characterization and antimicrobial activity of polyaniline Th(Iv) tungstomolybdophosphate nano-composite material: efficient removal of toxic metal ions from water, J. Chem. Eng., 2014, 251, 413-421.
27 N. E. Topp and K. W. Pepper, Properties of Ion-exchange Resins in Relation to their structure. Part I. Titration Curves, J. Chem. Soc., 1949, 3299-3303.

28 S. A. Nabi and Mu. Naushad, Synthesis, characterization and analytical applications of a new Composite cation exchanger cellulose acetate-Zr(Iv) molybdophosphate, Colloids Surf., A, 2008, 316, 217-225.

29 Y. Luo, S. Shen, J. Luo, X. Wang and R. Sun, Green synthesis of silver nanoparticle in xylan solution via Tollens reaction and its detection for $\mathrm{Hg}^{2+}$, Nanoscale, 2014, 1-12.

30 S. A. Nabi, S. Usmani and N. Rahman, Synthesis, characterization and analytical application of ion exchange material Zirconium(Iv) iodophosphate, Ann. Chim., 1996, 21, 521-530.

31 V. K. Sharma, R. A. Yngard and Y. Lin, Silver nanoparticles: Green synthesis and their antimicrobial activities, Adv. Colloid Interface Sci., 2009, 145, 83-96. 